\title{
The Theory of the Legal State
}

\author{
L. J. DU PLESSIS \\ Late Professor of Law P.U. for C.H.E.
}

\section{ABSTRACT}

In this article, which has not been publisbed before, the late Prof. du Plessis lays bare the philosophical roots of the liberal-democratic state, or the legal state, as be preferred to call it. After a recapitulative version of the the ory of the legal state, bet indicates the origin of this form in Greek philosopby and in Medieval thought. The stress, however, is on the Modern Era, in which be distinuishes two main periods in the development of the theory of the legal state:

* the jusnaturalistic period and the

- positivistic or formal period.

He argues that positivism has destroyed the original ideal of individual freedom in facts by regarding justice as a purely formal matter susceptible to any content. All guarantees for individual freedom whicb rested on a universal normative system fell away. The state defines its own competence and limits itself to legal forms in all its activities. The legal state thus merely becomes the state, any state as determined by fixed rules of its own making to which it binds itself in all its functioning. Law sinks to a mere form in which the juristic personality of the state manifests its supremacy, and from this there is only one step to the concept that the state is identical with law, so that any state necessarily is a legal state, and any state action which is formally correct, is legal. The article concludes with a brief representation of the author's own political and legal vision.

\section{GENERAL}

His torically this theory represents a reaction to arbibrary rule in certain welldefined forms and at the present day it is especially embodied in the liberaldemocratic state which is being threatened by the so-called dictatorships of international and national socialism as the modern embodiments of arbitrary rule.

The theory of the legal state posits:

* Legislation with continuous consent of a popular representation democratically elected. 
The Theory of the Legal State

- Application of the law by a politically independent and expert judicature.

- Strict legal circumscription of the powers of executive government and administration, especially excluding powers of legislation and judicial decision.

- Subjugation of all executive officers to the jurisdiction of the law courts.

- Delimitation of state functions in a fundamental law of a relatively inflexible character.

- Reservation of certain civil liberties from encroachment by government, either in a fundamental law or in common law.

The theory has a history starting from its origins in classical times, developing through a jusnaturalistic, mainly material, and a constitutional, mainly formal, period to its decline in the formalistic positivism of extreme democratism.

It divides into two clearly separated currents in its second period of development, viz that of Anglo-Saxon rule of law and of continental legal state theory.

\section{ORIGINS}

In a sense of course every state and the state as such is a legal state as being always determined by law and operating through legal categories, which does not mean that state and law are necessarily indentical as Kelsen maintains. But the theory of the legal state is not meant to be applicable to every state but only to a special historically developed kind or form of state, viz that indicated in the first section of this essay, the so-called demo-liberal state. As such it takes its origin from classical quasi-democratic theory.

The material aspect of the theory is fore-shadowed in Plato's and Aristotle's political ideal of government according to nature, which means according to the perfect essence of human virtue in society, that is to say according to the law of nature as later on developed in Stoic theory, the law of reason and equality and equity, as finally embodied in Roman private law. This material legal basis of the state is not, however, conceived as limiting the power of the state or of government, rather it is described as the natural content of the ideal state and of good government and law, at least as far as concerns the relations between the citizens and the education of citizens.

The formal aspect of the theory can also be traced to the teachings of Plato and Aristotle in so far as they considered the safest form of government 


\section{J. du Plessis}

to be one according to law, that is to say according to custom and legislation by a more or less popular body standing above the law courts and the administration. (Law in this sense was crystallized in Roman private law.) Meanwhile the contract theory as explanation of the basis of state authority had been mooted by the Epicureans and this also tended in the direction of binding government to popular consent in legal form.

All this referred more especially to legislation on private law. Public law itself was kept separate and was considered as being more freely at the disposal of government. This was changed by the advent of Christendom which in principle limited the power of the state to so-called secular matters and also bound public law to the law of God and nature as interpreted by the Church, which thus became the supreme arbiter of law, public and private. This brings us to the Middle Age, in which certain classical hints as to the natural basis of specific social groups as distinguished from the individuals and the state (and church) were developed under the influence of Christian doctrine and Germanic custom into a theory of the legal autonomy of corporations in the forms of guilds, municipalities and social orders (ordines). Even now the individual had not come into his right in as much as classical theory entirely subordinated him to the state and public law though it be in a position of relative equality with other individuals, while medieval theory kept him in subjugation to a variety of authorities, ecclesiastical, political, social etc.

The most characteristic feature of medieval theory is its concept of a complete system of divine and natural law which shapes and determines humar society as it were from above, a law derived from the will of God and natural reason. This system of law is considered to be the essence of positive law as laid down and adopted to changing human circumstances by the authorities of the church and the state and various autonomous communities.

The church is the highest authority but is in essence confined to the domain of grace, the state dominates the lower natural sphere of life and the head of the state, while subordinate to divine and natural law, is the supreme dispenser of positive law.

If, however, the state deviates from divine and natural law in laying down and administering positive law, it in so far forfeits its aurhority, and all subjects may be absolved from obedience by the church. This higher law thus 
The Theory of the Legal State

is the material basis of the legal state in medieval times and it is considered as definitely limiting the authority of the state in public and in private law.

Formally the legality of state action is guaranteed by the more or less contractual relation amongst the hierarchy of authorities above and below the state, which has as a consequence that important state action requires the concurrence of these other authorities and observance of the general feudal contracts between them, which may be enforced even by armed conflict, in as much as the state does not have the monopoly of force in medieval times, the several social organisations still being largely undifferentiated, the essentially economic guilds e.g. having important cultural, religious, fisical, military and legislative functions as well, etc etc.

At the end of the Middle Ages this medieval system is being undermined by nascent individualism and nationalism. Now the idea arises that the fundamental fact of nature is not a universal system of will and reason and law, but the free individual as a centre of independent will and sovereign reason in himself. So natural law becomes the product of the individual will, which is saved from choas by a national unification of the individual wills in the state, which then becomes the component of the individual wills by free consent and social compact, authorized by these wills to lay down the positive law to the advantage of the combined individuals. The freedom of the individual will generates the sovereignty of the national will, and the problem arises how to guarantee materially the jusnaturalistic content of the positive law as product of the sovereign will and how formally to organize the sovereign will so as to ensure the legality of its actions.

The Reformation did not have much trouble with this problem as it main tained the ideal of natural legal principles of all positive law embodied by the Creator in Scripture and in the natural constitution of human society, while discarding the supremacy of the church, and moreover in its Calvinistic form, which was the cause of modern parliamentary institutions, recognized the legal competence of all natural and historical social organizations, of each according to its own nature, thus formally ensuring legality by the requirement of co-operation between the state and these other organizations as represented in parliamentary institutions. But modern theory while dissolving human society into sovereign individuals felt the full impact of this problem. 


\section{J. du Plessis}

\section{The suinaturalistic period}

The first solution of this problem was offered by the so-called classical or jusnaturalistic theory of the law of nature as the basis of society and the state, the law of nature namely in its modern humanistic conception as the rational rule of liberty of the individual man.

At first theorists were content to base the sovereign will on an original compact of the individuals to subject themselves to one with a view to securing law and order or the general good, and further all emphasis was laid on the unity and indivisibility and absoluteness of sovereignty as the supreme source of all positive law. This was the line taken by Bodin and Grotius, who, however, at the same time maintained the regulative force of the law of nature. Thomas Hobbes, however, who conceived of the law of nature as one of chaos and barbarity, took the view that the founding of society and the sovereign state person pur an end to the rule of natural law, so that positive law is the original and free product of the sovereign will unfettered by any rule of nature.

Now this theory was so strongly opposed to the facts of the British constitution in which a rule of law more or less independent of the sovereign will had always been recognized, and moreover so unfavourable to the 17 th century opposition to start absolutism, that it found much less support in Eng land than on the continent of Europe.

The English common law and non-conformist reaction against the Hobbesian absolutism was further strengthened by the rise in philosophy of a less rationalistic current of thought which found in nature as empirical substratum not soluble into rational concepts and accordingly refused to allow the individual to be absorbed and submerged in a rationalistic system of artificially constructed sovereignty.

In this view the free individual is a permanent datum of nature, and natural law is preserved as the basis of the state so that sovereignty, while being based on the contractual unification of the individual wills into society, nevertheless remains bound to the original purpose of its institution viz the more effective maintenance of individual liberty. Thuswise the jusnaturalistic content of positive law as product of the sovereign will is materially guaranteed. The free individuals of the state of nature bind themselves by contract which is an institution of the law of nature (pacta sunt servanda), to unify their ge- 


\section{The Theory of the Legal State}

neral forces into civil society for the purpose of protecting the individual li berty of each by means of positive law, If therefore this purpose is not achieved the individual is absolved from his conditional contract. Nevertheless it is also conceded that the sovereign has to be guided by the common good and the conflict between common good and individual liberty is not resolved the sanctioning of revolution carries with it the constant threat of anarchy.

This theory also attacked the second part of the problem, viz how formally to organize the sovereign will so as to ensure the legality of its actions. This was done in the main by entrusting the wielding (execution) of the sovereign power to several distinct authorities which could mutually check one another and especially by reserving the most important power viz the legislative to the representative body or paliament which could be supposed to reflect the public will of society and to be powerful enough to make this will effective as against the other authorities in the state in the form of statute law. The difficulty of course remaining that the representative body may be falsified or frustrated or that a deadlock may result; and in any case there is no guarantee that even the representative body will always be minded to guarantee individual liberty. In fact a fully democratic sovereign may be most tyrannical against liberal liberty.

In any case this democratic representative constitution is pictured not only as the historic safeguard of liberty in England but as a postulate of the jusnaturalistic theory of individual liberty and in both its material and its formal aspects it is a development of suggestions thrown out by a whole series of late medieval theorists between the 14 th and 15 th centuries of whom the most important is Marsilius of Padua.

The classical exponents of the theory, however, are John Locke, Baron de Montesquitu and Jean Jacques Rousseau. Their relevant works should if possible be read and summarized in this connection.

Finally the jusnaturalistic period is concluded by a moralistic reinterpretation in idealistic vein on the continent by Kant, Fichte and Humboldt, and in utilitarian strain by Hume, Betham and Mill in England.

While maintaining the above outlined criticism of this theory as a whole its special merit must at the same time be underlined, in that it brought to the fore the unique value of the individual also in social and political relations not only in reference to the sphere of private law as in the Roman, ius gentium but in the domain of public law as well. 


\section{J. du Plessis}

John Locke who was educated in a nonconformist home and was by conviction an empiristic rationalist, published his political theory in his Two Treatises of Govt. (1690) directed against Filmer and Hobbes and in favour of the Glorious Revolution in England.

The general outline of his theory is sufficiently known and need not be repeated. The following six salient points, however, require notice. Just as the material of knowledge is derived from the individual sensations and reflections and only the relations between these are rationally determined, so the material of natural law is provided by individual property (in the special Lockian sence) and only the social protection of property, based on the jusnaturalistic social contract, is a matter for positive law. The material purpose of the social contract is none other than organized protection of the inborn natural human rights of the individual, termed by Locke his property. Yet by an intelligible anomaly the state is also required to ensure the public welfare the motto of his work actually is: Salus popul suprema lex esto. Locke's own definition combines these divergent purposes of the state into one seemingly harmonious whole (I. i. in fine): "Political power, then, I take to be a right of making laws with penalty of death, and consequently all less penalties, for the regulating and preserving of property, and of employing the force of the community, in the execution of such laws, and in the defence of the commonwealth from foreign injury, and all this only for the common good".

By property is understood life, health, freedom and material goods of the individual and all together are also styled liberty which was defined formally by Locke as follows ( 11 ): "Freedom of men under government is, to have a standing rule to live by, common to every one of that society, and made by the legislative power erected in it; a liberty to follow my own will in all things, where the rule prescribes not; and not to be subject to the inconstant uncertain unknown, arbitrary will of another man: as freedom of nature is to be under no other restraint but the law of nature".

The elements of this formal legality of the free state clearly are: legal certainty, equality before the law, separation of powers, popular consent to legislation, absence of other than legal restraint and of arbitrary rule - no one of which, however, is a guarantee for the material right of property.

The formal ideal is clearly and succinctly stated by Locke himself in the following words: "And so whoever has the legislative or supreme power of any 


\section{The Theory of the Legal State}

commonwealth, is bound to govern by established standing laws, promulgated and known to the people, and not by extemporary decrees, by indifferent and upright judges, who are to decide controversies by those laws; and to employ the force of the community at bome, only in the execution of such laws".

The legislature is constituted indirectly by the majority of the people, it is the supreme power, however, constituted, and yet as delegated by the people has no power further to delegate its legislative power. The legislative body ought only to meet intermittently for the passing of laws and ought not to execute the laws, so that the legislators may live under the laws passed by themselves and thus be careful to frame laws for the common good. The executive body on the other hand, while subordinate to the legislative, functions continously in as much as the laws require continuous execution. A separate power not regulated by the laws, while also usually entrusted to the executive body, is that for the management of external affairs, called the federative power, which is determined by the law of nature and seems to point to the prerogative powers of the British monarchy. (N.B.: The judicature is not specially mentioned in this connection as a separate power, and in the question above it is closely affiliated to the legislative power.)

It must be noticed that the legislature as once constituted by the community cannot be changed without overthrowing the existing state by revolution. Thus Locke's theory does not envisage any reformation of the constitution of the British legislature (rotton boroughs etc), yet he has no objection to allowing the executive by prerogative to reorganize the representation in parliament, which is an obvious anomaly; other prerogative powers are justified as remnants of a period of greater popular trust in rulers. These could be limited by the legislature as a whole.

The last resort is the appeal to heaven, that is to say revolution and reconstitution of the state by society. In that case, however, the executive really is the primary rebel in breaking the basic covenant and so reopening the conflict (rebellare) and then as Locke expresses it: "every one is at the disposure of his own will, when those who had, by the delegation of the society, the declaring of the public will, are excluded from it and others usurp the place, who have no such authority or delegation". In the last resort therefore the formal guarantee of individual liberty against the reason of state disguised as the common good is not the legislature or the separation of powers but revolution of the massed individuals. Because society is not viewed as materially 


\section{J. du Plessis}

defined and articulated but as formally constructed by means of a compact of free individuals, for the common good, the material liberty of the individuals and society cannot be formally guaranteed by a constitution which must continuously waver in unstable equilibrium between individual liberty and social good. Nevertheless Locke had succeeded in rasing the standard of individual liberty against the supreme power of the state in private and in public law.

The famous French theorist of the legal state Charles de Secondat, baron de Montesquieu, De l' Esprit des Lois is even more empiristically enclined than Locke and lays special emphasis on the necessity of a liberal constitution as a guarantee of individual liberty.

The constitution of the state he then analysis as determined by a variety of causes, but as a guarantee of liberty he fixes on a constitution on the model of that of England and especially characterized by a separation of powers with a vicw to mutual limitation of powers, so that the balance of the several powers of government while reducing the danger of tyrannical criminal legislation and execution conduces to the maintenance of individual civil. liberty - the form of the political constitution thus guarantecing the material of civil liberty, which is natural right. And yet civil liberty is defined without relation to natural liberty as the power to do what the laws require one to wish for and the absence of being forced to do what the laws forbid one to strive for. Liberty already tends to become absorbed into legalism, the material into the formal, as even more clearly evident in the teachings of Rousseau. Montesquieu, however, considers liberty as only one of the possible ends of the state as $\mathrm{e} g$ in England; the liberal constitution then is that one in which legislative and executive power are separated, while the legilative power, though not absolutely supreme, yet represents the people as a united whole; in such a constitution further the executive is separated into two, the one governed mainly by international law (Locke's federative power including part of Locke's executive power) and the other the power of judicature evidently governed by municipal law. The lawgiver must only legislate, so as not to be interested in the execution of the law, the executive only execute so as to be restricted in its use of power by the executed law and the judge only interpret fixed law so as to be bound by law not of his own making and to be forced to leave the execution of his sentences to the executive, etc.

In fact the formal law must be the ruling power in state and the law must be the embodied will of a true representative legislature, representing the people 
as a whole on the basis of a vote for every normal adult citizen. Yet Montesquieu makes a variety of concessions to the necessities of historical development and human weakness, allowing $\mathrm{e} g$ a veto power of the executive in lawmaking and a power of arresting and imprisoning suspected persons in time of emergency, as well as several aristocratic privileges.

In these several concessions the fundamental dualism in Montesquieu's conception is revealed, viz that between the civil state as the union of individual wills and the political state as consisting of the combined force of the community as wielded by the government. Nevertheless as modified by practice in the direction of allowing wider political power to the executive in a broad sense the theory of Montesquieu as combined with that of Locke had a profound influence in shaping the political constitution of the western world, especially in the United States in the general direction of a representative legislature and independent judicial control over the independent executive power.

Meanwhile the theory of empirism had advanced so far through the critiques of David Hume that reason had been reduced to a association of sensual impressions and now the ideal of human liberty and sovereignty veered round to the level of feeling and will. Jean Jacques Rousseau was the great prophet of the new human freedom as guaranteed by the consciousness or feeling of liberty to choose amongst several possible alternatives without constraint by natural law or even the laws of reason. In fact Hume had already denied the existence of reasonable law in a state of nature.

Rousseau then makes it his task not so much to explain the rise of the state as to revolutionize the constitution of the state so as to bring it into harmony with the natural human liberty of selfdetermination by free choice. For this purpose he uses the traditional ideology of the "contract social" but gives it a new content, in that it is conceived by him as a method for creating an infallible unified general will out of a multiplicity of particularistic individual wills which maintain their liberty by being combined into one. This general will is then declared amnipotent as being the essence of human perfection and so is competent to force recalcitrant individuals to be free. Against its supremacy all natural law or scientific reason breaks down and the only guarantee as to its humanity or essential justice is the formal method of its selfexpression viz by means of a universal meeting of the people to declare the law, and the complete subordination of the execurive power to this legal will - 


\section{J. du Plessis}

in fact, however, the guarantee against the arbitrariness of the supreme will is its sublimation into ideal justice. And in principle it is indeed sublimated in as much as it is conceived as a kind of ideal unity of the individual wills, as the true will of every individual although it may be at complete variance with his actual will, as the expression of the perfect human being which results from the transformation of natural man into a citizen by means of the social compact and under the influence of some semidivine original lawgiver. Even as the more concrete general will which issues into legislation of an illimitable, indivisible, inalienable sovereignty, in as much as the particular wills of the people (excluding the always particularistic women) gathered in direct, general assembly for legislation proceeding from all and directed to the equal and common good of all, cancel their mutual particularity and become universalized into unity, even as such the supreme power still remains fairly attenuated. But when Rousseau proceeds for practical purposes to introduce the principle of majority vote as determining legislation, we have the Leviathan naked and undisguised into which all natural liberty of the individual is absorbed, although in this case the Leviathan is not the government as representing the body politic but the massed individual citizens themselves expressing their majority will which cannot be represented in any way. Goverment then is only execution of the so expressed popular will by agents who can at any time be discharged, and the administration of justice simply the application of this law. These are no separate powers any more, but only subordinate and particulirized applications of the only sovereign will, that of the legislature which is the unity of the wills of all the citizens and as such the true embodiment of liberty in which each individual has become "comme Partie indivisible du tout".

So, while Locke raised the standard of individual natural liberty as a right against the governmental power, thus differentating the ideal of private law or civil law as the guarantee of right to the private person as such and Montesquieu sought a guarantee of civil liberty in the constitution itself, Rousseau proclaimed as the true and only basis of the civil law of liberty that organization of public law which ensures its being the direct expression of the general will of all the people as directed to the equal good of all - liberty resulting from equality before the law and this being based on universal equality in the making of the law, the idea of public law, thus being differentiated as the expression of the identity of will for public purposes generated in a community of free private persons without aristocratic privilege or any sectional organization. 
The construction of public law is now to serve as the guarantee of individual human liberty and so the material idea of individual liberty as purpose of the legal state recedes into the background and the scene is held by the more formal idea of a truly democratic constitution where law rules as being the general will. In fact these ideas are mutually exclusive as shown by Rousseau's phrase "to be forced to be free" and yet they are still combined in the written constitutions of the revolutionary period in France as if in complete mutual harmony. Actually the Leviathan emerged supreme from the conflict in Napoleon and yet one of the belated results was the code of civil law and another the judicial defence of private legal right in administrative law against encroachments by administrative officials of the executive power, which means that the ideal of individual liberty had in fact been realized in a rather cir cumscribed sphere.

By this time then, that is the last quarter of the 18 th century, the doctrine of natural law and right had fulfilled its function in generating the ideas of liberty through popular, sovereignty, supremacy of law, equality before the law and subordination of the executive power to law and the legislature. So the stage was set for the second period of the legal state theory in which the jusnaturalistic material aspect was superseded by the constitutional formal aspect, which change of accent was philosophically advanced by the victory of empirism in England through the labour of Hume and the rise of historicism on the continent. Law now come to be looked upon not as an embodiment of natural right but rather as the will of the (popular) sovereign-jusnaturalism was being replaced by democratic positivism. And the emphasis now is on the constitutional improvement of the expression of the popular will.

The abruptness of this change was, however, softened by the intervention of a period of speculation on the etnical (vide jusnaturalistic or legal) limitations of the sovereign will. In this period of transformation there was a clear distinction between the utilitarian English theory into produced by Jeremy Bentham and the idealistic German theory proceeding from Immanuel Kant

In fact from now on there is a distinct clearage between English and German thought, which is maintained into the second period of the theory of the legal state. 


\section{J. du Plessis}

English demo-liberal thought now bases itself on the common sense ethical concept of "the greatest happiness of the greatest number"and from this concludes: that the state should leave the individual to his own devices as much as possible and direct its public actions by the ideal of humanitarianism and organize itself on the lines of democratic parliamentary sovereignty and the rule of law as expounded by independent law courts with a bias in favour of the defence of private right against administrative arbitrariness in public law, a bias which in America was embodied in the written constitutions and reinforced by an extreme separation of powers.

This theory finally issues into the rule of law theory as expounded by Dicey This has already been briefly dicussed and we shall now proceed to a discussion of the continental theory of the legal state in the second period, prefacing a few remarks on the idealistic liberalism of Kant, which is the ethical basis of this theory.

Kant proceeds from the idea that the humanity of man is unassailably guaranteed only in the autonomy of the individual will as the permanent ethical idea of individual selfdetermination according to the categorical imperative of always acting so that the rule of this action can be conceived as a universal law. This absolutely excludes the determination of the will by any other will or by any force outside the will, especially by any factor of natural causation. The rationalistic schematisation of reality which was the ideal of rationalism up to now, had threatened to engulf human liberty in the dark current of causation, and this danger had to be cut off at the root by elevating the human will as the idea of liberty out of this causal concatenation. But now the coexistence of many individuals necessitates the mutual limitation of the liberty of individuals which is the idea of right, of which the ideal principle is a form of association in which the freedom of choice of one individual can coexist with that of all others. From this is deduced the ideal of the (relatively) democratic state and of positive law as the rule of hindrance of hindrances, and of international society as that of a democratic league of nations tending towards the establishment of eternal peaces Peace however requires supremacy of power which at least outwardly destroys individual liberty of choice - as even Kant.was forced to admit.

The supremacy of political power in laying down positive law is according ly now an accepted tend and idealistic liberalism limits itself to applying to the state the ethical ideal of the limitation of its power, to the hidrance of hin- 


\section{The Theory of the Legal State}

drance of liberty, which according to Kent is the ideal form of law being morality applied to external acts, and the constitutional ideal of democratic legislation and subordination of executive government to law. Kant however, restricts political right to the class of independent citizens - the bourgeoisand only gradually the democratic ideal succeeds in universalizing political citizenship.

Kant himself, however, only justified gradual reformation and rejected any form of revolution against the powers that be. At the basis of this theory there remains the idealistic ethical principle of human liberty as moral autonomy in the most absolute sense, which in Fichte's first period is accentuated into absolute individualism. It may be worthwhile to summarize the steps of Kant's descent from this ethical ideal to the theory of the democratic legal state in its formal period on the continent of Europe - a descent which is itself the essence of formality. Thuswise - the form of moral legality in general which characterizes the categorical imperative of ethics is the bridge between pure practical reason and the phenomenal reality of nature in human life, the form of liberty in the relation of mutual freedom of choice in society is the bridge between right according to pure practical laws of reason and empirical social life, and the form of the democratic general will is the bridge between this idea of justice and the positive law of the civil state.

The judgement of pure practical reason as to the justice of external acts (i e morality on its external side) is thus declared to be essence of positive law "eine blosz empirische Rechtslehre ist (wie der hölzerne Kopf in Phadrus' Fabel) ein Kopf der schon sein mag, nur schade, dazz er kein gehirn hat". But this essence is so formal, this remnant of natural law so attenuated, that it only amounts to the sanctioning of force with a view to hindering hindrances to liberty of choice in the coexistence of individuals in so far as such liberty of choice can coexist with like liberty of every one else according to a general law of freedom. Valid law and right is materially only constituted by the force of the general will, though derived from the formal ideal of individual liberty in external acts as based on moral liberty of selfdetermination.

After Kant on the continent a reaction set in against individualism and in this development the general will was metamorphosed by romanticism and historicism into the national mind as the source of all law. This national mind was at first represented as personified in the historically developed state and Hegel idealised the state itself as the moral personality of humanity and as such supreme. 


\section{J. du Plessis}

Later on even idealism itself was replaced by sociological positivism which saw as the moving power behind the state the socio-economic forces working in the historic development of society and by the Marxian socialism this idea was defined as that of the class struggle in which the ruling class necessarily dominates society by its power and uses the state as the instrument of its power. By the dialectical development of history however the ruling class of the time, the bourgeois capitalists, was according to this view destined to be overthrown by the proletarian class of labourers.

National socialism again is a combination of this theory with nationalistic historicism and issues in the view that the power behind the throne is the socializing race basis of nationality.

These theories are opposed to those of the legal state, which dominated the scene during the 19th century, as theories of the power state. But even in these theories the ideal of liberty and equality survives though in a socilized form, in Marxism in an egalitarian society, in national-socialism in an organic society.

But let us return to the theory of the legal state in its second or formal period which dominated the scene in the middle of 19th century.

\section{The positivistic or formal period on the continent}

In this period two results had been achieved as a consequence of jusnaturalistic and ethical speculation and revolutionary practice, viz (1) in the domain of private law the idea of equality in private rights of the private person as such, no privileges nor slavery and no distinction of race, creed or nationality, and (2) in the domain of public law the abolition of all feudal relations of a public nature including guild organisation and a clear distinction of legislature, administration and judicature with relatively democratic representation in the legislature and the supremacy of parliamentary law.

On the other hand the idea that the private person as such could have any legal right as against the state as lawgiver was made impossible by the theory that all law is positive and state-produced, while the various social groups and organizations (excluding political parties) had not yet been recognized as clothed with any original rights or legal capacity, but were considered as creatures of the state and its law, as far as their legal status was concerned. 
It was expected that the representative legislature should guarantee all private and social rights.

Consequently all emphasis was laid on the desideration of formal legality in all state action and the supremacy of democratic legislation as a guarantee of individual liberty is so far as historicism and positivism did not content itself with declaring the supremacy of the historically evolved state power or accepting as legally binding all that the state as such decreed. Pure positivism, however, was a later growth which culminated in Kelson's identification of state and law.

F.J. Stahl eg., writing in the first half of the 19th century, still considered law as a second-rate social morality characterized by force, restrictiveness and externality, yet nevertheless as essentially objective ethos. As such, however, it was necessarily imperified and even its justice not above reproach: law is in a sense bad but certain morality, and thus even in its positivity not necessarily good justice. Further, law is social morality as formed by a nation in a state and thus only applicabel to those acts of individuals which affect the nation with reference to the external fashion of social life.

Law as social morality regulates the social existence of the individual, of the family, of local communities, corporations and orders, of the state and the community of states and of the church. As such it is in a sense determined by the social structure and restricted by its own externality; it is further restricted by its purpose of guaranteeing rights to the individual in society, so that public administration which has a wider purpose than law, is in part extrajural. Law and the state do not correspond completely, yet law is positive and positive law is what the stae commands though it be immoral and unjust and though the state may administratively act outside law itself. Formally positive law is always binding. Law may, however, also originate from the historical background of the state, viz the volkgeist-i.e. common or customary law.

There are individual and social moral determinants of law, but positive law which also regulates a part of state action is freely created by the nation and state-as such. For the state is no organism or corporation but the authoritative moral self-expression of the nation. As such it is determined by the moral personality of the nation and its laws, but the state itself is the incarnation of this moral personality as the king is the personification of the state. Con- 


\section{J. du Plessis}

sequently the state is the supreme guardian of external or social morality by means of positive law. Thus morally the state ought to be a legal state.

On the other hand the state is the formally supreme dispenser of the law, the legal guaranties of its legality can only be internal to itself, a result of its own character and constitution; outside of the state there is no basis for legal outonomy because all social groupings are part of the state. Formally the state is the sovereign lawgiver of formal law which has an outward sanction though not necessarily an inward vadility.

So the form of the state and the state action acquires supreme importance with a view to ensuring its legality. Not what it guarantees to the individual or society, is important or rather decisive for its legality, but how it acts in forming its guarantees and sanctions, in which the main points are the form of the legislature and the circumscription of administration by law, al though Stahl also posits a mysterious interaction between national mind, sovereign state will and law in determing the constitution of the state and the character of its law.

Stahl also differentiates between judicature and administration in that the first has as its main purpose maintaining the right of individuals and groups (justice), while the latter aims at the common good within the limits of law and right. Both are determined by law, but in the second case rather as by an outward fence - this being a reminiscence of the so-called Polizeistaat in Germany. And in any case there is no appeal from the Administration to a court of law even on a point of law, but only from a lower Administration authority to a higher, except in the matter of criminal punishment which in fact is a question of administration but is closely connected with individual right that it can only be based on the sentence of a court of law. So there are also certain private rights which are exempted from administrative interference, such as a real property, paternal power, etc. However, in the case of conflict between judicature and administration and for certain other purposes a special administrative court may be required. But the legislature itself is free from legal restraints.

Still, in the form of constitutional monarchy it incorporates or personifies the national mind and thus is itself potentially determined by law which as political ethos is a product of the national mind. Later theorists in this movement more especially developed the idea of self-government and the extension of administrative judicature and combined this with the gradual socialisation of law 


\section{The Theory of the Legal State}

This development revealed the conflict between liberalism and democratism in the theory of the legal state - liberty versus equality - Locke versus Rousseau, especially in the development of the theory in France.

Of this further development little need be said except to point out how the theory of the legal state was further formalized into pure democratism and legalism, until finally the state was considered a result of sociological forces in a material and formal sense, and was declared to be a legal state however constituted by these forces - in as much as all states and any state must necessarily issue in law. This final development : consequently destroyed the idea of the legal state as a special kind of ideal state in as much as is declared all states equally to be legal states, in this respect revealing a retrogression even as against the theory of the power state which at least retained an ideal of socialization.

Let us, however, briefly return to the later development in the second period of the legal state before its final dissolution.

\section{STATE SOVEREIGNTLY IN MODERN GERMANY BY EGGERSON}

In this theory a certain legal autonomy of the nation and social groups or of society is recognised but this autonomy is not juridically (legally) based on the essential nature of these group forms, but on their will as sanctioned by the state in its recognition of custom as a source of law and in its sanction of statutes and regulations of corporations in so far as not opposed to the public interest as interpreted by the state and its laws. The state remains legally supreme and produces formal law of its own free will though in material interaction with national and social forces, and all that remains for the ideal of the legal state as a restraint upon arbitrariness is the constitution of the state on a socially representative basis and the testing of administrative acts according to the law of the legislature by an independent judicature, without any clear recognition of the special principles of administrative justice.

At the background of the law-producing power of the state and other authorities there still remains the ideal of social necessities and interests which constitute centres of jural personality as bearers of rights (and duties), individual personality as well as social personality, with the state as the all-embracing and consecuently supreme personality. 


\section{J. du Plessis}

The state ideally considered is the supreme conciliator of social interest conflicts and is materially determined by this conciliation in its nature as a legal state; yet nevertheless law itself positively considered is the free product of the state and adminstration is the free pursuit of the public good within the limits of the law. The state integrates society into harmony by limiting itself to legality by means of its constitutional balance of powers and administrative adjudication.

With growth, however, of pure positivism in a sociological sense the conclusion could hardly be evaded that the state is no more than the product of society though it may finally be considered as a juristic person and even as a supreme juristic person and thus as the formal source of supreme law in which it defines its own competence and limits itself to legal forms in all its activities. The legal state then becomes merely the state, any state, as determined by fixed rules of its own making to which it binds itself in all its functioning. Law sinks to a mere form in which the juristic personality of the state manifests its supremacy, and from this there is only one step to the concept that the state is identical with law, so that any state necessarily is a legal state - the extreme positivistic relativism in the theory of the state and the law as expounded by Kelsen.

While the liberalism of Locke had been replaced by the democratism of Rosseau towards the end of the first period, now the sociological insight into the dangers of democratic tyranny in the party system and the pressure of interest groups caused by revulsion from democratism to constitutionalism and rule of law and from that to pure relativistic legalism, as against the frank return to socialistic or nationalistic power politics, in fact the socialistic approach has welnigh destroyed the conception of individual private rights from which the theory of the legal state set out.

The decline of the theory of the legal state - negative and positive criticism of the humanistic theory.

In the final period of the theory of the legal state towards the second half of the nineteenth century the process of its self-destruction is completed. Its basic ideal of individual sovereignty of the human personality which had in its first stage generated the idea of private right of liberty against the state and of popular sovereignty in legislation within the state, had in the second period been transformed into the ideal of the national mind which expresses itself in law and right and embodied itself in the state as the creator of positive law according to national genius, which law itself is the gaurantee of justice and as such must be judicially maintained against the administration by independent 


\section{The Theory of the Legal State}

courts of justice. Now, however, in the third period positive sociology in the world of theory and socialism in the world of practice had exposed the state as the mere reflection of social power relations without an inner ideal content of individual or national personality and personal right, and law as the regularisation of these power relations.

So private right is changed from a state-free sphere of right into a fortuitous law-free sphere of life in society which is hedged out by social solidarity as its continually issues in law and legal dury; , and popular sovereignty is metamorphosed into the socially determined despotism of the majority which is always right only because there is no absolute right any more; and the legal determination of justice as well as the judicial limitations of administrative discretion, the purely formal gaurantees of legal right, are constantly whittled down by the urgent pressure of social necessities. The theory of the legal state then finally successively retreats into the defensive position of state law as a means or formal category of social culture, of law as the self expression of the state as juristic personality pass excellence, or at least as one of the many social personalities, of law and state as identical normative systems guaranteed as legal by the special scientific method of their construction without any relation to social reality and all the ethnical-political postulates of outdated humanism - Ahrens; Damstaedter, Jellinek, Kelsen).

Yet nevertheless meanwhile a new conception of the legal state has arisen, which is based on the material right of various natural and historic social groups. This furnishes a basis for a positive criticism of the humanistic theory. The vitium originis of this theory is the humanistic concept that human reason or will is the sovereign source of all positive law, which leads to the conclusion that there can be no positive right against the sovereign will and that law is only formally determined by its origin from the sovereign will and thus without material legal content, although it may be determined in its content by external forces, economic, psychological, biological or what not. The question then only is where will the sovereign will is found or how it is constituted, whether it is localized in the individual or the state or several social groups or according to the laws of social development of the moment.

As against this concept Calvinism adheres to the conviction that law is materially determined by the Creator of the Universe and in principle revealed in Scripture and in nature and society as historically developed, and formally promulgated by various social authorities, by each according to its destination and nature, and that the state is not the source of all positive law but only of 


\section{J. du Plessis}

state law (public and social and private) and that its law is determined by its destination and nature as the only maintainer of law and right by means of the organized force of the territorial community which is based on nationality in modern times.

It is the maintainer of private law which is based on the jural needs of the individual as such in his relation with other individuals as such, it is the integrator of social law according to the principle of the jural needs of national homogeneity on the basis of the destination and nature of the several social groups of natural and historic origin, it is the formulator of public law for the national state in its relation with other states on the basis of the historical destination of the particular state and the nature of the state as such.

From this it follows that the legal or jural state must be so organized that it can best formulate state law in accordance with its nature and the needs of the community, that it can interpret law impartially according to the right of the individuals and the internal authority of the several social groups and that it can maintain the needs of social justice by the force of the community according to the exigencies of public force.

Accordingly the legislature must represent the nation in its unity and its diversity (by the incorporation of social groups in advisory capacity), the judicature must be impartially constituted but so as to be fair with all social needs and the executive must combine authority with expertise and universality. In this connection the work of the judicature is of supreme importance as the interpreter of law and executive regulations, so as to save the autonomy of the individual and the social groups as against the demands of national unity and public order in the application of private and social law and vice versa of administrative law as such. This task can only be accomplished by clearly differentiating the several cosmological laws which qualify the autonomy of all human activities - according to their several functions.

If the state through its judicature or otherwise fails in this duty of realizing formal law on the basis of supra-voluntary right, its acts are not only unjust but strictly illegal, and although no power within the state is justified in using force against it, every individual and every social group of cosmological authority is entitled to disregard its dictates as contrary to law even if clothed in all the forms of law. And in fact such dictates sooner or later prove their own 
The Theory of the Legal State

illegality by causing chaos instead of order, as not being capable or regulating social intercourse.

The state in forming its own law thus is not free to establish this arbitrarily, but just as all other social groups are determined by their cssential nature in establishing their internal laws, so the state only produces law in the strict sense when it realizes its own essential nature in correlation with the other group forms within it and the individuals in their interrelation as such. This law may also be more or less righteous as judged by the idea of right, but that does not in full affect its legality. Besides, the state in constituting itself by constitutional law is bound to the present historical basis of its being, viz. the political organization of the nation, which when the established state is shifted off this basis rises into statchood by assimilating to itself the political force of the community, and this is legal revolution. 